\title{
Socratic Impulse, Secular Tendency, and Jewish Emancipation: A Comparison between Simone Luzzatto and Moses Mendelssohn
}

\section{Introduction}

Since antiquity, the legendary figure of Socrates has embodied the human desire for knowledge, and since the earliest theological controversies, he has symbolised the first authentic free thinker as well as a victim of social and religious intolerance. The role of Socrates as a representative of secular knowledge within the framework of the struggle between philosophy and revelation was greatly thematised during the eighteenth century, which celebrated him as a paradigm of reason, a model of secular virtue, "certainly not an atheist one, but one which was independent of the dogmas of the priests, [...] the archetype of the free thinker in matters of faith." ${ }^{1}$ For this reason, the character of Socrates was imbued with a new secular pietas, which must be considered a significant expression of the Enlightenment's concerns about the question of religion.

According to Leo Strauss, the Socratic philosophical method reflects the original meaning of the term as a way of life devoted to the realm of knowledge and a search for the truth. Strauss makes a distinction between this concept of philosophy and that of philosophy as a mass of doctrines and a system established by history. ${ }^{2}$ In his view, Socrates's philosophy embodies the term's original meaning because it consists on the one hand of an awareness of human ignorance towards fundamental issues and on the other of the eros which prompts inquiry and the search for the truth. And indeed, an awareness of the uncertainty of any solution and of our ignorance of the main aspects of philosophical inquiry is the main feature of the philosopher's search for truth and his way of life; namely, a way of life that is incompatible with the biblical one. As part of the great discussion of the opposition between Jerusalem and Athens within Strauss's thought, there is an ambivalence between the Bible and Greek philosophy concerning how to deal with morality and which is the best way of life: philosophers attempt to answer to these questions by relying on their reason and not merely obeying the laws of a particular tradition, thereby opposing biblical hu-

\footnotetext{
1 Raymond Trousson, Socrates devant Voltaire, Diderot et Rousseau: la conscience en face du mythe (Paris: Lettres modernes, 1967), 18.

2 See Leo Strauss, "The Mutual Influence of Theology and Philosophy," Independent Journal of Philosophy 3 (1979): 114.

2 OpenAccess. (c) 2020 Michela Torbidoni, published by De Gruyter. (cc))BY-NC-ND This work is licensed under the Creative Commons Attribution-NonCommercial-NoDerivatives 4.0 License. 
mility, which is grounded in fear and piety. ${ }^{3}$ Strauss expounded the two different approaches to life through the story of Abraham and the example of Socrates in the following way: the former obeys an unintelligible command without hesitation; the latter, Socrates, despite his belief that Apollo was commanding him, nevertheless did not react "in unhesitating obedience, but in examining an unintelligible saying of Apollo." 4 Socrates questions the truth of the Delphic oracle's statement that he is the wisest man and in doing so, his rational inquiry replaces the blind obedience to divine orders requested by the biblical tradition. In light of this example, the Socratic form of inquiry must be interpreted as the authentic expression of human wisdom in opposition to the divine one.

Despite the radical opposition between Jerusalem and Athens defended by Strauss's view, his speculation about Socrates has the merit not only of having highlighted the secular tendency of Socratic philosophy-namely, Socrates's attempt to free the mind from the fetters of dogmatism and his impact on the social orderbut also, and even more surprising, of having linked Mendelssohn's enthusiasm for the figure of Socrates and Simone Luzzatto's Socrates, Or On Human Knowledge (1651). In a small passage in his early writing on Mendelssohn's Phaedon, Strauss quoted a sentence written by Mendelssohn in a letter to his friend Thomas Abbt at a time when his Phaedon (1767) was almost complete:

I am putting my reasons into Socrates' mouth. [...] I need a pagan so as not to have to get involved with revelation. ${ }^{5}$

The above sentence taken from Mendelssohn's letters is completed by a handwritten marginal note in which Strauss adds a reference to Luzzatto and his Socrates. ${ }^{6}$ The similarities that Strauss had perhaps seen between Luzzatto's book and Mendelssohn's Phaedon seem to be mostly found in Mendelssohn's philosophical decision to speak through Socrates's voice. According to Strauss, this fact reflected not only Mendelssohn's struggle against the Scholastic tradition, but also his struggle against the very concept of tradition; namely, "prejudices," especially those of the revealed religions. In Strauss's opinion, Socrates and Plato attracted Mendelssohn's interest because they were philosophers who did not believe in revelation; that is, they were "rational pagans."7

3 See Chiara Adorisio, Leo Strauss lettore di Hermann Cohen: dalla filosofia moderna al ritorno agli antichi (Florence: Giuntina, 2007), 170-74.

4 Leo Strauss, Jewish Philosophy and the Crisis of Modernity: Essays and Lectures in Modern Jewish Thought, ed. Kenneth Hart Green (Albany, NY: SUNY Press, 1997), 111.

5 Letter from Moses Mendelssohn to Thomas Abbt of July 22, 1766, in Leo Strauss, On Moses Mendelssohn, ed. and trans. Martin D. Yaffe (Chicago: University of Chicago Press, 2012), 34.

6 Yaffe mentions this handwritten note and directs the reader to Leo Strauss's Gesammelte Schriften, Band II: Philosophie und Gesetz-Frühe Schriften, ed. Heinrich Meier (Stuttgart: J.B. Metzler Verlag, 1997). See Strauss, On Moses Mendelssohn, 34 n. 40.

7 Strauss, On Moses Mendelssohn, 33-34. 
Strauss's interpretation suggests that the choice of the pagan Socrates may have been methodological in order to fulfil Mendelssohn's wish to speak free from religious concerns and thus also to raise criticism of traditional prejudices. This consideration, when viewed in connection with the marginal quotation, thus also invites us to reflect on the role of the pagan Socrates within Luzzatto's book, and most of all to what extent this figure may be bound to the history of Jewish emancipation. The cases of Moses Mendelssohn and Simone Luzzatto, as representatives of the German Jewish Enlightenment and Baroque Italy respectively, provide meaningful evidence of the close connection between the use of Socrates and his critical approach and their struggle for the rights of Jews in society.

The present comparison is a preliminary work aiming to provide some hints of a wider topic that will not be fully realised here. However, this brief overview of the Socratic impulses of Mendelssohn and Luzzatto may be considered an interesting starting point in order to examine not only their philosophical projects, but also the social and religious claims behind them. Starting from the better-known case of Mendelssohn's rational Socrates and proceeding to Luzzatto's sceptical version of him, the great complexity of the Jews' relationship to their surrounding culture will be explored. This will help to add some further considerations on the state of the Jews in early modern Italy and the German Aufklärung.

As we will see, under Socrates's flag, both Mendelssohn and Luzzatto pursue a common aim; namely, the foundation of a universalistic human community. However, what is interesting and more problematic in this respect is the different methodological approaches to such a figure. While Mendelssohn uses Socrates as a means of disseminating his original optimism and trust into the universalistic value of reason, careful to conform to the cultural tendencies of the Enlightenment, Luzzatto makes Socrates the mediator of his provocative sceptical pessimism towards human certainties. These two contrary methodological approaches invite us to reflect on the freedom of speech already achieved by this early modern Venetian rabbi, on the multi-level challenge issued by his philosophical writing in which Socrates was the main character, and above all on the real status of the Jews in Venice, where a rabbi could state that his book had been written by a "Venetian Jew."

\section{Mendelssohn's Socrates of Reason}

Within eighteenth-century Jewish thought, however, Socrates must be seen as an ambivalent figure of reason, and Moses Mendelssohn's commitment to achieving a true and coherent synthesis between rationalist philosophy and Jewish religion properly shows this ambivalence.

We should not overlook the fact that within the framework of intellectual history, the figure of Socrates also embodied crucial religious and political issues during the early German Haskalah (1680-1720): in an era of intense criticism of Lutheran orthodoxy and its relationship to the Aristotelian philosophical tradition in German uni- 
versities, ${ }^{8}$ Socrates had usually been taken into account independently of the Platonic tradition and praised as the philosopher of moral questions who had turned his attention from the contemplation of natural things to human customs and behaviours. ${ }^{9}$ However, according to the German Lutheran theologian Johann Franz Budde (1667-1729), "the figure of Socrates assumes an important role: his struggle against the Sophists more or less foreshadowed the struggle of modern philosophy against the empty metaphysical debates and arrogance of the Scholastics (supercilium scholasticum)."10

A similar attitude may also be found in Mendelssohn's decision to put his reasoning into the mouth of Socrates, a pagan, in his Phaedon (1767): this was meant to fulfil his wish to speak free from religious concerns and thus reflected his attempt to underline the universalistic foundation of philosophy, theology, and above all reason as the common ground of every religion. Phaedon was an essay about what reason can know regarding the immortality of the soul when it is not guided by revelation; namely, by counting only on its own capacities. Mendelssohn's decision to write such a work was prompted by his admiration for Plato and Socrates, which was rooted in his opposition to the dogmatism and pedantic authority of Scholastic philosophy. In putting forth strictly philosophical arguments for the immortality of the soul, the dialogues contend that such reasonings must take place independently of the demands of religion.

Mendelssohn's portrayal of Socrates greatly idealised his wisdom, his patience and impartial philanthropy, his devotion to the laws of his homeland until his death, his liberal attitude towards religious traditions, and his decisive opposition to prejudices and superstitions. ${ }^{11}$ Although Socrates lived in a time that did not share the oppressive theological circumstances of Mendelssohn's century, nevertheless Mendelssohn described him by focusing less on his personality and more on his cultural context, which seemed to reflect Mendelssohn's own dilemma:

He had on the one hand to conquer the prejudices of his own education, to enlighten the ignorance of others, to refute sophistry and calumny of his adversaries, to bear poverty, to contend against established power, and, what was still more hard than either, to dissipate the dark terrors of superstition. On the other hand, the feeble understanding of his fellow citizens required

8 From 1660 in Germany, and more specifically following the foundation of the University of Halle, a religious circle that was highly critical of Lutheran orthodoxy began disseminating its ideas: its promoters, such as Christian Thomasius, Johann Franz Budde, and some members of the Pietist community, challenged Lutheran traditions and encouraged a new study of the relationship between Christianity and classical philosophy. On this topic, see Guido Bartolucci, "Jewish Scepticism in Christian Eyes: Jacob F. Reimmann and the Transformation of Jewish Philosophy,” in Yearbook of the Maimonides Centre for Advanced Studies 2018, ed. Bill Rebiger (Berlin: De Gruyter, 2018), 145-64.

9 Gregorio Piaia and Giovanni Santinello, eds., Models of the History of Philosophy. Volume II: From the Cartesian Age to Brucker (Dordrecht and New York: Springer, 2011), 357.

10 Piaia and Santinello, 357.

11 See Alexander Altmann, Moses Mendelssohn: A Biographical Study (Philadelphia: Jewish Publication Society of America, 1973), 157-58. 
to be managed with great tenderness, that he might draw no reproaches upon himself, or lessen the influence which the poorest religion has on the morals of weak minds. ${ }^{12}$

The goal of Mendelssohn's Socrates is to eradicate "the dark terrors of superstition" in favour of a broader horizon made by an enlightened concept of a universal God which unifies reason and religion and thus may be shared by different cultures. The philosophical project of Phaedo's Socrates is thus intimately linked to Mendelssohn's personal intellectual experience and desire for a space in which speculative thought could be independent from any religious group:

Wisdom knows a universal fatherland, a universal religion, and if it tolerates divisions, it does not tolerate the unkindness, misanthropy of such divisions, which you have made the foundation of your political institutions.-This is how, I think, a man like Socrates would think in our days and seen from this angle, the mantle of modern philosophy, which I have given him, would not seem entirely unfitting. ${ }^{13}$

In his use of a pagan speaker, Mendelssohn was attempting to overcome the particularity of a specific religious creed and to join Enlightenment's universalist project; however, the entire book must also be read as an answer to a Christian readership. According to Miriam Leonard, Mendelssohn engaged in this dialogue in order to appease the long-standing Christian critique that accused the Jews of having neglected the immortality of the soul:

From the Christian perspective, the question of immortality was just one more indication of the essential lack of Judaism. Paradoxically, immortality is a Greek not a Jewish idea. Jewish philosophers like Philo had to turn to Plato to fill in the gaps of Jewish theology. In this version, Platonism is not so much the antithesis as the supplement to Judaism. Plato hardly represented the dangerous lure of paganism. Jews needed Plato to become better Jews. ${ }^{14}$

Socrates is anything but Mendelssohn's mouthpiece; he leads Mendelssohn's opinion to the conclusion that this world has been conceived so as to make those of its inhabitants who are endowed with reason continue in their progress towards perfection and happiness. From this assumption, he deduced that it was impossible to conceive of a divine wisdom which would allow the interruption of this progress and cause them to lose the results of their efforts. ${ }^{15}$ Mendelssohn strengthens this argu-

12 Mendelssohn, Phaedon, in Schriften zur Philosophie und Ästhetik, ed. Fritz Bamberger and Leo Strauss, vol 3.1 of Gesammelte Schriften. Jubiläumsausgabe, ed. Alexander Altmann et al. (Berlin: Akademie Verlag, 1972), 15-16. From now on, I will refer to this edition as JubA. The English translation is taken from Willi Goetschel, Spinoza's Modernity: Mendelssohn, Lessing, and Heine (Madison: University of Wisconsin Press, 2003), 119-20.

13 JubA, 3.1:151-2; Goetschel, Spinoza’s Modernity, 121.

14 Miriam Leonard, “Greeks, Jews, and the Enlightenment: Moses Mendelssohn's Socrates,” Cultural Critique 74 (2010): 194.

15 See Mendelssohn, JubA, 3.1:115. 
ment, which is in itself sufficient to demonstrate the immortality of the human soul, and underlined that human beings have a need to believe in the existence of a life after death. ${ }^{16}$

Based on Plato's Phaedo, Mendelssohn's dialogue on the immortality of the soul put forth a persuasive plea for the recognition that human individuality is grounded in every person's inalienable right. His use of Socrates to expound his philosophynamely, a Greek philosopher who represented a common universal point of reference in Western philosophy-was the key to the immense success of his Phaedon.

Mendelssohn's essay is more than simply evidence of the conflict between the Enlightenment and religion: on the one hand, the figure of Socrates reflected Mendelssohn's philosophical search for the acknowledgment of the universal value of reason, and through him, he was able to present his philosophical project to a greater public. On the other, the Socratic impulse which permeated Mendelssohn's life and work was sometimes misinterpreted by the Christian side and seen as an attempt to distance himself from Judaism and come closer to Christianity. For this reason, behind the epithet "the German Socrates," 17 which was bestowed on him by his contemporaries, there was not only the great acknowledgment that Mendelssohn received from the Christian intellectual world, but also persistent prejudice concerning his Judaism and the expectation of his conversion.

An example of this concern is the caustic letter exchange between Mendelssohn and Johann Kaspar Lavater. As soon as Mendelssohn had established himself in the republic of letters, he was obliged to face Lavater's public challenge, which had a devastating effect on his life. In his translation of Charles Bonnet's La palingénésie philosophique ${ }^{18}$ the Swiss philosopher and theologian addressed a dedicatory epistle to Mendelssohn. Since Lavater had interpreted Bonnet's arguments as a demonstration of the truth of Christianity meant for non-Christians, he invited Mendelssohn to either refute these arguments or else to do "what Socrates would have done if he had read [Bonnet's work] and found it irrefutable"; ${ }^{19}$ namely, to convert to the religion of truth and in so doing, to do what, in his opinion, reason would demand.

Mendelssohn, deeply offended by this public provocation, was also compelled to react, because his failure to answer to Lavater's attack could have been seen as an incapacity to dismiss Bonnet's arguments and could also have raised suspicion to-

16 See Allan Arkush, Moses Mendelssohn and the Enlightenment (Albany, NY: SUNY Press, 1994), 57. 17 On this topic, see Christoph Schulte, Die Jüdische Aufklärung: Philosophie, Religion, Geschichte (Munich: C.H. Beck, 2002), 199-206.

18 Charles Bonnet's book, La palingénésie philosophique, ou, Idées sur l'état passé et sur l'état futur des êtres vivans, was published in Geneva in 1769 by Claude Philibert and Barthelemi Chirol.

19 Mendelssohn, Zueignungsschreiben Johann Caspar Lavaters an Moses Mendelssohn in Schriften zum Judentum I, ed. Simon Rawidowicz, vol 7.1 of Gesammelte Schriften. Jubiläumsausgabe, ed. Alexander Altmann et al. (Berlin: Akademie Verlag, 1930. The English translation is taken from Moses Mendelssohn, Writings on Judaism, Christianity, and the Bible, ed. Michah Gottlieb, trans. Curtis Bowman, Elias Sacks, and Allan Arkush (Waltham, MA: Brandeis University Press, 2011), 3. 
wards his sincere commitment to Judaism. At the same time, his denial of Bonnet's arguments could have been interpreted as an implicit attack on Christianity. He was thus obliged to take a public stand with regard to Judaism, which was what he had above all wished to avoid. In this way, Lavater created a situation which undermined the openness and fairness of the free speech of the republic of letters. The solution that Mendelssohn devised masterfully allowed him to avoid such an insidious trap. In an open letter to Lavater, he focused on Judaism's tolerant attitude towards nonJews by arguing that it was a religion based on the universal laws of rational morality, the Noahide Laws, which do not demand the conversion of others, contrary to Christianity. ${ }^{20}$

Mendelssohn's involvement in the emancipation of the Jews consisted, as is wellknown, in his mediating role between two apparent opposites, the Enlightenment and Judaism. His main goal was to create the foundations for a Judeo-German literature by propagating an image of Judaism that could suit the contemporary conception of reason. The uneasy compromise between reason and revelation that preoccupies Mendelssohn in his Phaedon is also at the heart of his most famous work, Jerusalem, Or On Religious Power and Judaism (1783), in which he attempted to show that Judaism was not only reconcilable to the Enlightenment, but also that it provided the most convincing model of a life ruled by reason.

According to David Sorkin, Mendelssohn's wished-for synthesis may be situated within what he calls the "religious Enlightenment," a term that points out the complexity of his relationship to the larger culture. ${ }^{21}$ On the one hand, there was his support of an ideal compatibility between reason and divine revelation based on the cultivation of intellectual perfection and the practice of universal ethics; an ideal prompted by "an egalitarian impulse, holding that all human beings (not just élite philosophers) could know metaphysical truth"22 and by the refusal to search for an ultimate truth. On the other, there was his reliance on what Bernard Septimus has defined as the "Andalusian tradition," ${ }^{23}$ meaning a flexible approach to Judaism within medieval Jewish philosophy which did not reject rationalism itself, but established boundaries to it by subordinating philosophy to piety and limiting the horizon of human knowledge. For this reason, according to Sorkin, Mendelssohn seems to use novel means to achieve conservative ends.

20 See Mendelssohn's open letter to Lavater, Mendelssohn, JubA, 7.1:7-17.

21 David Sorkin, Moses Mendelssohn and the Religious Enlightenment (London: Halban, 2012 ), 25.

22 Sorkin, $\mathrm{xx}-\mathrm{xxi}$.

23 Bernard Septimus, "Nahmanides and the Andalusian Tradition," in Rabbi Moses Nahmanides (Ramban): Explorations in His Religious and Literary Virtuosity, ed. Isadore Twersky (Cambridge, MA: Harvard University Press, 1983), 34. 


\section{Luzzatto's Sceptical Socrates}

Little more than a century earlier, a Venetian rabbi, fully committed to the defence of the Jews, had adopted the figure of Socrates as a spokesperson for his philosophical, religious, and political ideas: Simone Luzzatto. One of the chief rabbis of Venice, Luzzatto is known for having published a plea to prevent the expulsion of his people from the city, Discourse on the State of the Jews, in 1638. Among the many arguments put forth in this work, Luzzatto also underlined the universalistic foundation of Judaism. He stated that the human community must be grounded in the observance of the precepts of natural morality and in some cognition of the superior cause; ${ }^{24}$ in this way, he showed that he shared the widespread belief of his time that humanity consisted in acknowledging the existence of a superior cause and in sharing the precepts of natural morality. ${ }^{25}$ In this work, Judaism is presented as being deeply bound to this universal community thanks to its traditional struggle against misbeliefs due to its inner adherence to rational thinking:

No other precept is reiterated as frequently in the Scripture as the prohibition against magic, the judicial magic of the times, necromancy, and all other vain observances and abominable idolatries. For they are all the offshoots of superstition, which is nothing but an abuse, or worse, a waste product of true religion and the legitimate worship of God. Indeed, Moses was not so worried about chasing impiety from the world as he was about rooting out superstition. For a regular series of events, a chain of connected causes, or even the anatomy of a base, ugly little animal is proof of the existence of God and a confutation of atheism. ${ }^{26}$

In his response to Tacitus's denigration of Judaism, Luzzatto wants not only to demonstrate that Scripture itself is against idolatry, but also to underline the rational nature of the Jewish religion:

I cannot fully understand what he wishes to infer when he states that the ancient Jews were oppressed by superstition, while he himself affirms first that they "conceive of one god only, and that with the mind alone."27

However, the idea of Judaism having a universal rational foundation is only briefly mentioned in the Discourse. After all, how could this book, which was an official defence of the Jews in light of dangers to their lives in Venice, be the right place to un-

24 See Simone Luzzatto, Discourse on the State of the Jews of Venice, ed. and trans. Giuseppe Veltri and Anna Lissa (Berlin and Boston: De Gruyter, 2019), 134.

25 See Alessandro Guetta, Italian Jewry in the Early Modern Era: Essays in Intellectual History (Brighton, MA: Academic Studies Press, 2014), 97.

26 Luzzatto, Discourse, 171-73.

27 Luzzatto, 172-73. The quotation from Tacitus is taken from his Histories, 5.5.18-19, in Tacitus, Histories: Books 4-5. Annals: Books 1-3, trans. Clifford H. Moore and John Jackson (Cambridge, MA: Harvard University Press, 1931), 183. 
fold such a philosophical argument? Luzzatto would only properly articulate this idea more than ten years later in his second book, Socrates, Or On Human Knowledge, in which the famous Socrates and his critical attitude are allied to the pattern provided by sceptical philosophy. This combination of elements thus created the ideal premise for an inquiry able to delve into what Luzzatto defined as the "human community" described above.

Mendelssohn's Socrates is like a saint, a positive character who entirely relies on the certainty of reason. His Phaedo amply documented Mendelssohn's reliance on the abilities of reason, because it was an essay meant to show what reason can know regarding the immortality of the soul when it is not guided by revelation; namely, by counting only on its own capacities. Luzzatto's Socrates is rather an anti-hero; he is insolent, restless in his inquisitive approach to life, and substantially sceptical. In the extended title of Socrates, Or On Human Knowledge, the premises of Mendelssohn's Phaedon seem to be reversed, as it states that it is "a book that shows how deficient human understanding can be when it is not led by revelation.” He belongs to the sceptical tradition going back to Michel de Montaigne's philosophy, with which Luzzatto was very conversant. Montaigne's use of Socrates's attitude and irony ${ }^{28}$ was meant to overcome the borders established by rituals, superstitions, and prejudices. His goal was to discover the universality of rational thinking and at the same time to build the autonomy of the conscience, because according to Montaigne, every human being bears in himself the entire human condition. ${ }^{29}$ Like Montaigne, Luzzatto, through the figure of Socrates, defines the guidelines of his philosophical project: the possibility of overcoming the mere singularity of his Jewish identity and achieving universality through his speculative thought.

The pattern followed by Luzzatto's Socrates was strongly inspired by Sextus Empiricus's Outlines of Scepticism: the ten tropoi lead his inquiry through the subjectivity of human perception, a source of continual illusion, or the inconstancy of the state of the whole up to the final acknowledgment of the inscrutability of any object by itself. ${ }^{30}$ Like Sextus, Luzzatto's Socrates is persuaded that the suspension of judgement (epochē) is the correct attitude towards the world, because every statement is subject to irreconcilable conflicts (diaphōnia). Equipollence, which demands the suspension of judgement which they believe restores peace of mind or tranquil-

28 See Alexander Nehamas, The Art of Living: Socratic Reflections from Plato to Foucault (Berkeley, Los Angeles, and London: University of California Press, 1998), 101-27.

29 See Montaigne, The Complete Essays, ed. and trans. M.A. Screech (London: Penguin, 2003), 3:2. 30 On the impact of Sextus Empiricus's Outlines of Scepticism on Luzzatto's Socrates, see Michela Torbidoni, "Il metodo del dubbio nel Socrate di Simone Luzzatto," in Filosofo e rabbino nella Venezia del Seicento: Studi su Simone Luzzatto, ed. Giuseppe Veltri (Rome: Aracne, 2015), 183-245, and Giuseppe Veltri, Alienated Wisdom: Enquiry into Jewish Philosophy and Scepticism (Berlin and Boston: De Gruyter, 2018), 217-24. 
lity (ataraxia), reigns in every inquiry that sceptics undertake. ${ }^{31}$ Socrates is here not only masterfully managing Sextus's Outlines, but he is also well acquainted with the Academic scepticism of Carneades, whereof Cicero's Academics is the chief source. The "probable" (from the Greek pithanon) plays a major role in Luzzatto's book, in which it is defined as the "North Star in his journey through life," showing thus that it is consistent with the sceptic's instruction to follow the probable in the absence of truth.

Socrates here embodies the restless human curiosity which questions past and present beliefs without stopping to wonder what the future will bring. He questions anthropocentric cosmology by recalling disrupting thinkers such as Lucretius or Bruno and referring to the impious theory of the existence of an infinite number of worlds or the idea of the eternity of the world. Through Socrates, Luzzatto aims to break the illusion of mankind's superiority, and on the contrary, he upholds its marginalised position in the universe: this stance is also strengthened by his comparison between human beings and animals and the fact that he reduces the gap between them. Luzzatto's goal is to show the miserable state of every human being who arrogantly boasts of his wisdom or is absolutely convinced that he is following the right belief or custom.

Following modern scepticism, Luzzatto comes to acknowledge the relativity of the customs and beliefs of every civilisation to every epoch: his arguments lead to an unavoidable "isostheny" between all views, past and present. Luzzatto's Socrates champions the idea that no certainty exists, but rather that everything is true relative to its era and to the culture to which one belongs. An example of this is found in the following passage:

However, in addition to this, is there any opinion that, despite having strongly persisted for a long time instead of ending its life and dying out in accordance with all other human things, turns out not to be temporary in relation to the infinite future and the undefined posterity to come? Rather, every day, we experience that many opinions held in high esteem and consideration by antiquity nowadays turn into mere fabulous fantasies and ridiculous tales. ${ }^{32}$ The worshipped ox, deified by the Egyptians along with many other brutes, already begins to be considered as frenzied and mad by us Greeks. ${ }^{33}$

Luzzatto's Socrates fulfils a double task: there is an evident pars destruens meant to demolish traditional certainties in every field from astronomy to ethics. This

31 On the legacy of Pyrrhonism, see Richard H. Popkin, The History of Scepticism from Savonarola to Bayle, rev. ed. (Oxford: Oxford University Press, 2003) and The High Road to Pyrrhonism, ed. Richard A. Watson and James E. Force, repr. ed. (Indianapolis: Hackett, 1993).

32 Living by experience and without opinions plays a relevant role in Sextus's arguments against dogmatic assertions; see Outlines of Scepticism 2.246.

33 The reference to the Egyptians' worship of animals also occurs in Discourse, 168-71, where Luzzatto quotes Juvenal, Satires 15.1-4. The same topic, together with the same quotation, is found in Montaigne's Essays in 2:11, 462-64. 
part, which is the most consistent in the whole of the Socrates, pursues the daring undertaking of undermining the traditional body of knowledge based on Aristotelian philosophy, because it is evidently no longer able to contain the immense changes and discoveries that arose during the seventeenth century. The reader of this first part of Luzzatto's book will find the Socratic celebration of ignorance-meant as an awareness of not knowing anything that may claim the name of truth and the critical use of reason-to be a tool for refusing everything dictated by tradition or blindly accepted as religious belief. Thanks to his Socrates, the rabbi expounded a refined criticism of the alleged truths or dogmata of his time established by an authorial tradition which demanded to be obeyed and not questioned. This part of the book, as has been seen, was made possible thanks to Luzzatto putting ancient and modern sceptical strategies into the mouth of Socrates, the most restless mind in Western culture.

However, the long pars destruens prepares the basis for the pars construens: the uncertainty disseminated throughout the book generates a sense of loss which creates bonds between human beings rather than separating them. Doctrine, social wealth, beauty, custom, religious ceremonies-namely, the major sources of human division-are, in Luzzatto's treatise, all subjected to doubt, and the human being ends up being stripped of all his convictions that are opposed to God and Nature. Indeed, the universality that Luzzatto's thinking aims to achieve is not atheistic, but is rather a theistically inspired religiosity which does not need any particular creed. Specifically, the final part of his Socrates shows that in his view, proper religious behaviour conforms to reason, is universal, and is against superstition and degenerate beliefs:

For it is sufficient for my defence that you observe the public and private reasonings that I have always delivered concerning the reverence due to the first and worthiest cause, which moves and rules everything. Indeed, I have always promulgated that the cognition that one has of it and the veneration that is due to it come not only from subtle and wide-ranging deductions, but were also given to us along with milk by Nature itself. Hence, it follows that the human mind is so inclined and favourably disposed to religion and divine worship that if it were deprived of such a pursuit, he would not be very different from brute animals.

I have never despised or omitted [to perform] ceremonies or institutions ordered by our city for the observance of religion, but I have always publicly offered sacrifices in accordance with the rites of my homeland, in appropriate places, at the right moment, and in a legitimate manner. And if I sometimes took a position against the ignorant by reprehending them for their ridiculous superstition or degenerate religion, I was not then attempting, as the Giants did, to expel Jupiter from the sky, but rather trying to remove those despicable concepts which disfigured the beauty and grace of the true religion in their minds.

Therefore, I have often solemnly said to those who were truly prudent that they must protect themselves from the infection of superstition, an epidemic and serious disease of the people. They [must] be aware that often the religion of the vile common people is abominable blas- 
phemy for wise men and that the true temple of God is in the wise man's mind, where He is adored through offerings of love and sacrifices of veneration. ${ }^{34}$

Although Luzzatto's opinion is presented very prudently in this passage, it is nevertheless evident that he deploys reason as the true temple of God. Only there, in his opinion, does true religion seem to find shelter from "the infection of superstition" and "abominable blasphemy."

Luzzatto's conception of Nature is intended to increase this common ground shared by human beings: his sceptical Socrates promotes a naturalistic morality based on Nature as a "lover of equality" able to provide mankind with a profitable tool that should be the only reliable guide through life; namely, the probable, described as coming directly "from the hands of Nature." Luzzatto portrays a sort of genealogy in which Nature must be considered the true source of moral values:

You must not even doubt that in discrediting its own judgement and accusing it of falsity, the court of conscience attended by the human mind would be debased and lacking in authority, because it will be replaced by the majesty of Nature, which will lead the way more decorously towards the good and remove the evil. ${ }^{35}$

Moral virtues are indeed, according to Luzzatto's Socrates, “daughters of the probable," and thus "legitimate grandchildren of Nature itself." ${ }^{36}$ Nature is thus an impersonal entity free of any traditional features, which therefore offers Luzzatto a solution to the dizzying results of his free inquiry into dogmatic knowledge. Luzzatto's focus on Nature seems to continue to fulfil his attempt to bring the discussion to a universal level. According to him, humanity must be conceived "not as something abstracted and excluded from universal Nature, but as something included in it that should comply with it and be ably ruled by it like the other mundane things." 37

Luzzatto's arguments concretely erode dogmatic beliefs as a source of separation and division in society and indirectly put forth the premises of unity and equality among human beings; namely, the acknowledgment of what he had already defined as the "human community" in his Discourse. In his view, this larger community shares the uncertainty of knowledge and beliefs as the only possible certainty and may rely only on a natural morality based on the probable and on the faith in God which dwells in the mind and not in religious ceremonies, securing itself from any form of degeneration. In this way, Luzzatto constructed an indirect apologetic discourse which fosters tolerance and extends the borders of the concept of

34 Luzzatto, Socrates, Or On Human Knowledge, ed. and trans. Giuseppe Veltri and Michela Torbidoni (Berlin and Boston: De Gruyter, 2019), 478-79.

35 Luzzatto, 470-71.

36 Luzzatto, 476-77.

37 Luzzatto, 306-7. 
community by creating a new space for more acceptance of social and religious pluralism.

Luzzatto could develop this pars construens only thanks to the Greek Socrates. After reading Luzzatto's Socrates, one may note that most of the author's speech is delivered by Socrates himself. It may furthermore be seen that the text displays a rich variety of classical doctrines, including gnoseology, ethics, psychology, medicine, mathematics, geometry, and astronomy, embellished by passages and verses taken from classical poems and plays. With the exception of a few direct quotations from medieval and Renaissance Italian literature-such as Dante's Divine Comedy, Ariosto's Orlando Furioso, and Tasso's The Liberation of Jerusalem, which were typical for a learned Italian Jew ${ }^{38}$-and two from the Bible (Ecclesiastes and Proverbs), Luzzatto's book openly prefers the Greeks and Latins as speakers; namely, Greek philosophers and mythological and legendary figures or politicians from this ancient world, as well as Greek and Latin literature for the quotations between the paragraphs. Questioning Luzzatto's choice of the classical world for the setting of his philosophical scepticism therefore requires us to engage with the long-lasting relationship between Jewish thought and religion and classical philosophy, which began during the Middle Ages thanks to Jewish encounters with texts from the Greek philosophical traditions $^{39}$ and was revived during the Renaissance, strongly impacting the passage to modernity. During the Middle Ages, when the teachings of the two textual traditions seemed to contradict one another, a variety of methods for resolving contradictions and synthesising these traditions emerged, which spurred the development of medieval Jewish religious philosophy and gave rise to public controversies. Ancient philosophy, which emerged as a polemical middle ground on which to engage criticism during the Middle Ages, experienced a rebirth during the Renaissance, when many classical treatises were edited, translated, and commented on. ${ }^{40}$ This revival was a challenging moment because it allowed a transition from a philosophical setting shaped by Scholastic Aristotelian doctrine to modernity. Ancient wisdom (Platonism, Neoplatonism, Stoic ethics, Atomism, or Scepticism) continued to be examined for its "neutrality" in religious matters and theological controversies which were deeply connected to Aristotelian authority and became extremely important during the sixteenth and seventeenth centuries. Classical philosophy was therefore seen as a safe zone for those intellectuals who were committed to free thinking or to the new experimental science, and for this reason, it was an excellent bridge of dialogue and comparison between Jews and Christians.

38 See Asher Salah, “A Matter of Quotation: Dante and the Literary Identity of Jews in Italy,” in The Italian Judaica Jubilee Conference, ed. Shlomo Simonsohn and Joseph Shatzmiller (Leiden and Boston: Brill, 2013), 167-96; Guetta, Italian Jewry in the Early Modern Era.

39 See Adam Shear, "Science, Medicine, and Jewish Philosophy," in The Cambridge History of Judaism. Volume 7: The Early Modern World, 1500-1815, ed. Jonathan Karp and Adam Sutcliffe (Cambridge: Cambridge University Press, 2017), 522-49.

40 See Michael Heyd, “Introduction,” Science in Context 15, no. 1 (March 2002): 1-8. 
As in Mendelssohn's case, Luzzatto's erudition in secular and Christian learning also allowed him to engage in a solid dialogue with the learned people outside the ghetto and even to gain the respect and attention of those Christians with whom he was acquainted. There is indeed some evidence which clearly testifies to the regard in which he was held among non-Jewish Venetians and foreigners: the way he argued in defence of the Jews in his Discourse inspired and constituted the pattern of another plea on behalf of the Jews made between 1659 and 1660 by a Venetian senator of the Loredan family, twenty-one years after the publication of Luzzatto's book. ${ }^{41}$ Recent studies have furthermore shown that scientists like the astronomer Ismaël Boulliau, who was in the service of the French librarian and erudite humanist Jacques Dupuy, enjoyed the company of the wisest rabbis of the Venice ghetto, such as Leone Modena and Simone Luzzatto, for book collection and theological debates. ${ }^{42}$ Furthermore, there is evidence in Giulio Morosini's work Via della fede mostrata a' gli ebrei (1683) that Luzzatto was asked to be the arbitrator in a public debate between two brothers concerning the prophecy of Daniel. ${ }^{43}$

The celebration of Luzzatto's erudition and wisdom among the Gentiles is evidence of the intense dialogue and intellectual exchange he undertook with the Christian world. However, as in Mendelssohn's case, this openness was sometimes misinterpreted by Christians: the Franciscan Luigi Benetelli, in his invective work I dardi rabbinici (Rabbinical Arrows) published in 1705, mentioned Simone Luzzatto and Leone Modena as being known for addressing their works only to a Christian readership. Benetelli interpreted Luzzatto's behaviour and work as a wish to convert or an inclination to Christianity. It is not surprising indeed that Benetelli should have classified Luzzatto and Modena among the so-called evangelical rabbis (rabbini evangelici), meaning those who follow the Gospel but do not do so openly in order to not offend their coreligionists. ${ }^{44}$ The Franciscan strengthened his statement by mentioning some rumours that Cardinal Gregorio Barbarigo reported to him; namely, that Luzzatto wanted to convert to Christianity on his deathbed, but that his coreligionists

41 See Giuseppe Veltri and Gianfranco Miletto, "Difesa inedita del senatore veneziano Loredan in favore degli ebrei nel 1659-60 basata sul Discorso di Simone Luzzatto," in Filosofo e rabbino, 249-74. 42 See Giuseppe Veltri and Evelien Chayes, Oltre le mura del ghetto: Accademie, scetticismo e tolleranza nella Venezia barocca (Palermo: New Digital Press, 2016), 121-46.

43 See Giulio Morosini, Via delle fede mostrata a' gli ebrei (Rome: Stamperia della Sacra Congregazione de Propaganda Fide, 1683), 13-14. Morosini reports that Luzzatto stated: "As you know, the text we are currently discussing leaves all the most excellent rabbis in a state of perplexity, and they are so upset that they almost do not know whether they are in Heaven or on earth." Furthermore, Morosini wrote that after a few similar words, Luzzatto puts a finger to his lips and said: "Be quiet, if I may ask, because if we continue speculating on the prophecy of Daniel, we should all become Christians. I cannot deny that it shows very clearly that the Messiah arrived some time ago. However, whether this was Jesus of Nazareth or not, I do not want to state my opinion too hastily" (my translation). 44 See Luigi Benetelli, I dardi rabbinici (Venice: Domenico Lovisa, 1705), 19. 
did not allow any Christian, regardless of their social standing, to be present during the last moments before he died. ${ }^{45}$

Contrary to Mendelssohn's case, the scant amount of information concerning Luzzatto's intellectual life in Venice does not provide any evidence concerning his opinions or reactions in this regard. However, this short overview may be considered helpful to initiate an exploration of the meaning of this Jewish Socratic impulsenamely, the critical and anti-dogmatic approach to established knowledge-and how it was perceived from a Christian perspective.

\section{Conclusion}

The comparison between Mendelssohn and Luzzatto is useful here to understand the many implications involved in the use of Socrates by Jewish authors. For both of them, speaking through Socrates becomes a way to make their philosophical views reach a wider readership and reflects their wish to be seen only as far as their intellectual value is concerned. Mendelssohn and Luzzatto share the portrait of Socrates as a free thinker and free speaker beyond any boundaries; they both celebrate his critical attitude towards degenerated forms of beliefs, against superstition, in favour of a spirituality deeply rooted in reason and natural morality. For both of them, the figure of Socrates implicitly becomes a means of fostering their struggle for Jewish emancipation: according to Mendelssohn, Socrates is the mediator of his strong belief in the power of reason to build a community of human beings as estimators of speculative thinking which overcomes religious, social, or ethnic boundaries.

As far as Luzzatto's Socrates is concerned, he embodies the sceptic who inquires and demolishes every certainty, causing the apparently solid castle of beliefs established as undoubtable certainties over the centuries to collapse. From the ashes of this, his sceptical Socrates leads the way for a common ground based on natural morality and a faith in God which, in order to maintain its integrity and avoid blasphemy, can only be celebrated in the mind and not with external ceremonies.

Through the figure of Socrates and Socratic dialogue, the two philosophers achieve not only the goal of saving religion from degenerated forms of beliefs, but also that of fostering critical and free inquiry into dogmatic traditional knowledge and furthering one's self-knowledge in dialogue with others. Socrates therefore becomes a means of overcoming the borders of religious division and preparing the ground for a larger community; he was thus a medium for removing Judaism's particularistic features and instead stressing its universal content. Most of all, the Greek philosopher embodies the cultural role of philosophy and "secular" knowledge within the framework of Judaism; namely, the emergence of a group of intellectuals who gave

45 Benetelli, 19. 
priority to such study, at least in their private lives, over the traditional Halakhic focus of the rabbinic élite.

It is also crucial to underline the revival of Socrates's critical spirit among Jewish thinkers because it may be considered as a possible beginning of Jewish philosophy, which may be identified in the very moment when the traditional bonds holding the community together begin to collapse, occurring when tradition starts to be perceived as the antithesis to progress and progressive thinking. Jewish philosophy may therefore be interpreted as a response to this perception and also as the emergence of new questions usually articulated by modern philosophers concerning individuality and community, the commensurability of reason and revelation, and the historisation of tradition. ${ }^{46}$

In his great work on Jewish philosophy, Daniel Frank specified that "there are problems that arise at the end of the tradition, at a time when a certain distancing from the tradition has occurred" 47 and also that this was not an issue of interpreting or understanding tradition, but of questioning it. The use of Socrates may document the way Jewish philosophy interweaved with emancipation: it refers to the intellectual experience of those Jewish thinkers who were challenging the monolithic ground of tradition and inquiring into their own identity not only as a community, but as individual citizens in a Christian society. These Jews were those who developed personal relationships with Christians through the medium of philosophy: by doing so, they began to emancipate the individual from the sole identity that the Jewish community offered to him and started to gain a double acknowledgment.

Finally, it must be pointed out that while Mendelssohn made Socrates the interpreter of his ideas in search of a way to find harmony between his religion and a more general education, Italian Jewish thinkers like Simone Luzzatto were already able to link their Jewish religion to humanistic education and thus to express themselves via the figure of Socrates and celebrate his genius. ${ }^{48}$ The use of Socrates made by the Venetian rabbi Luzzatto substantially supports the thesis that early modern Italian Jewish culture must be explored more carefully as an important intellectual foundation of the programme to improve the status of the Jews of Europe in the late eighteenth century. As has been underlined by Adam Sutcliffe, "in many different early modern European contexts, Jews found ways to establish themselves on a firmer footing in the communities in which they lived without making any appeal to ideal of legal normalization or political equality, which would have been almost entirely anachronistic until the 1780s." 49 Through the maintenance of community

46 Daniel H. Frank and Oliver Leaman, eds., History of Jewish Philosophy (London and New York: Routledge, 1997), 4.

47 Frank and Leaman, 5.

48 See Jehuda Bergman, "Sokrates in der Jüdischen Literatur," Monatsschrift für Geschichte und Wissenschaft des Judentums 80 (1936): 13.

49 Adam Sutcliffe, “Toleration, Integration, Regeneration, and Reform," in The Cambridge History of Judaism, ed. Jonathan Karp and Adam Sutcliffe (Cambridge: Cambridge University Press, 2017), 1063. 
concord, shared spaces, and inter-confessional interactions, the early modern period experienced a concrete Jewish-Christian coexistence in addition to the political and theological stances which only affected these exchanges in a collateral way. ${ }^{50}$ Furthermore, one should reconsider the paradoxical impact of ghettoisation on Jewish culture, because rather than "eroding its distinctiveness, it provided, behind the ghetto walls, a secure home for its autonomous development, influenced by the dominant culture while also to some extent sealed from it. [...] Far from making Jews and Christians invisible to each other, this in fact provided the basis for more robust and self-conscious encounters across this boundary of difference."51

\section{Bibliography}

Adorisio, Chiara. Leo Strauss lettore di Hermann Cohen: dalla filosofia moderna al ritorno agli antichi. Florence: Giuntina, 2007.

Altmann, Alexander. Moses Mendelssohn: A Biographical Study. Philadelphia: Jewish Publication Society of America, 1973.

Arkush, Allan. Moses Mendelssohn and the Enlightenment. Albany, NY: SUNY Press, 1994.

Bartolucci, Guido. "Jewish Scepticism in Christian Eyes: Jacob F. Reimmann and the Transformation of Jewish Philosophy." In Yearbook of the Maimonides Centre for Advanced Studies 2018, edited by Bill Rebiger, 145-64. Berlin: De Gruyter, 2018.

Benetelli, Luigi. I dardi rabbinici. Venice: Domenico Lovisa, 1705.

Bergman, Jehuda. "Sokrates in der Jüdische Literatur." Monatsschrift für Geschichte und Wissenschaft des Judentums 80 (1936): 3-13.

Bonnet, Charles. La palingénésie philosophique, ou, Idées sur l'état passé et sur l'état futur des êtres vivans. Geneva: Claude Philibert et Barthelemi Chirol, 1769.

Frank, Daniel H., and Oliver Leaman, eds. History of Jewish Philosophy. London and New York: Routledge, 1997.

Goetschel, Willi. Spinoza's Modernity: Mendelssohn, Lessing, and Heine. Madison: University of Wisconsin Press, 2004.

Guetta, Alessandro. Italian Jewry in the Early Modern Era: Essays in Intellectual History. Brighton, MA: Academic Studies Press, 2014.

Heyd, Michael. "Introduction." Science in Context 15, no. 1 (March 2002): 1-8.

Israel, Jonathan. European Jewry in the Age of Mercantilism, 1550-1750. 3rd ed. London: Littman Library of Jewish Civilization, 1998.

Kaplan, Benjamin J. Divided by Faith: Religious Conflict and the Practice of Toleration in Early Modern Europe. Cambridge, MA: Harvard University Press, 2007.

Leonard, Miriam. “Greeks, Jews, and the Enlightenment: Moses Mendelssohn's Socrates." Cultural Critique 74 (2010): 183-99.

Luzzatto, Simone. Discourse on the State of the Jews of Venice. Edited and translated by Giuseppe Veltri and Anna Lissa. Berlin and Boston: De Gruyter, 2019.

50 See Benjamin J. Kaplan, Divided by Faith: Religious Conflict and the Practice of Toleration in Early Modern Europe (Cambridge, MA: Harvard University Press, 2007).

51 Sutcliffe, "Toleration, Integration, Regeneration, and Reform," 1064. See also Jonathan Israel, European Jewry in the Age of Mercantilism, 1550-1750, 3rd ed. (London: Littman Library of Jewish Civilization, 1998), 67-98. 
Luzzatto, Simone. Socrates, Or On Human Knowledge. Edited and translated by Giuseppe Veltri and Michela Torbidoni. Berlin and Boston: De Gruyter, 2019.

Mendelssohn, Moses. Phaedon. In Schriften zur Philosophie und Ästhetik. Edited by Fritz Bamberger and Leo Strauss. Volume 3.1 of Gesammelte Schriften. Jubiläumsausgabe, edited by Alexander Altmann et al. Stuttgart: Friedrich Frommann, 1972.

Mendelssohn, Moses. Writings on Judaism, Christianity, and the Bible. Edited by Michah Gottlieb. Translated by Curtis Bowman, Elias Sacks, and Allan Arkush. Waltham, MA: Brandeis University Press, 2011.

Mendelssohn, Moses. Zueignungsschreiben Johann Caspar Lavaters an Moses Mendelssohn in Schriften zum Judentum I. Edited by Simon Rawidowicz. Volume 7.1 of Gesammelte Schriften. Jubiläumsausgabe, edited by Alexander Altmann et al. Stuttgart: Friedrich Frommann, 1974.

Montaigne, Michel de. The Complete Essays. Edited and translated by M.A. Screech, London: Penguin, 2003.

Morosini, Giulio. Via delle fede mostrata a' gli Ebrei. Rome: Stamperia della Sacra Congregazione de Propaganda Fide, 1683.

Nehamas, Alexander. The Art of Living: Socratic Reflections from Plato to Foucault. Berkeley, Los Angeles, and London: University of California Press, 1998.

Piaia, Gregorio, and Giovanni Santinello, eds. Models of the History of Philosophy. Volume II: From the Cartesian Age to Brucker. Dordrecht and New York: Springer, 2011.

Popkin, Richard H. The High Road to Pyrrhonism. Edited by Richard A. Watson and James E. Force. Reprint ed. Indianapolis: Hackett, 1993.

Popkin, Richard H. The History of Scepticism: From Savonarola to Bayle. Revised ed. Oxford: Oxford University Press, 2003.

Salah, Asher. "A Matter of Quotation: Dante and the Literary Identity of Jews in Italy." In The Italian Judaica Jubilee Conference, edited by Shlomo Simonsohn and Joseph Shatzmiller, 167-96. Leiden and Boston: Brill, 2013.

Schulte, Christoph. Die Jüdische Aufklärung: Philosophie, Religion, Geschichte. Munich: C.H. Beck, 2002.

Septimus, Bernard. "Nahmanides and the Andalusian Tradition." In Rabbi Moses Nahmanides (Ramban): Explorations in His Religious and Literary Virtuosity, edited by Isadore Twersky, 11-34. Cambridge, MA: Harvard University Press, 1983.

Shear, Adam. "Science, Medicine, and Jewish Philosophy." In The Cambridge History of Judaism. Volume 7: The Early Modern World, 1500-1815, edited by Jonathan Karp and Adam Sutcliffe, 522-49. Cambridge: Cambridge University Press, 2017.

Sorkin, David. Moses Mendelssohn and the Religious Enlightenment. London: Halban, 2012.

Strauss, Leo. Gesammelte Schriften, Band II: Philosophie und Gesetz-Frühe Schriften. Edited by Heinrich Meier. Stuttgart: J.B. Metzler Verlag, 1997.

Strauss, Leo. Jewish Philosophy and the Crisis of Modernity: Essays and Lectures in Modern Jewish Thought. Edited by Kenneth Hart Green. Albany, NY: SUNY Press, 1997.

Strauss, Leo. On Moses Mendelssohn. Edited and translated by Martin D. Yaffe. Chicago: University of Chicago Press, 2012.

Strauss, Leo. "The Mutual Influence of Theology and Philosophy." Independent Journal of Philosophy 3 (1979): 111-18.

Sutcliffe, Adam. "Toleration, Integration, Regeneration, and Reform." In The Cambridge History of Judaism. Volume 7: The Early Modern World, edited by Jonathan Karp and Adam Sutcliffe, 1058-88. Cambridge: Cambridge University Press, 2017.

Tacitus. Histories: Books 4-5. Annals: Books 1-3. Translated by Clifford H. Moore and John Jackson. Cambridge, MA: Harvard University Press, 1931. 
Torbidoni, Michela. "Il metodo del dubbio nel Socrate di Simone Luzzatto." In Filosofo e rabbino nella Venezia del Seicento. Studi su Simone Luzzatto, edited by Giuseppe Veltri, 183-245. Rome: Aracne, 2015.

Trousson, Raymond. Socrates devant Voltaire, Diderot et Rousseau: la conscience en face du mythe. Paris: Lettres modernes, 1967.

Veltri, Giuseppe. Alienated Wisdom: Enquiry into Jewish Philosophy and Scepticism. Berlin and Boston: De Gruyter, 2018.

Veltri, Giuseppe, and Evelien Chayes. Oltre le mura del ghetto: Accademie, scetticismo e tolleranza nella Venezia barocca. Palermo: New Digital Press, 2016.

Veltri, Giuseppe, and Gianfranco Miletto. "Difesa inedita del senatore veneziano Loredan in favore degli ebrei nel 1659-60 basata sul Discorso di Simone Luzzatto." In Filosofo e rabbino nella Venezia del Seicento. Studi su Simone Luzzatto, edited by Giuseppe Veltri, 249-74. Rome: Aracne, 2015. 
